\title{
English in an EFL Context: Teachers' and Learners' Motivations for English Language Learning
}

\author{
Fatemeh Zarrabi ${ }^{1}$ \\ ${ }^{1}$ School of Education, Monash University, Melbourne, Australia \\ Correspondence: Fatemeh Zarrabi, School of Education, Monash University, Melbourne, Australia. Tel: \\ 61-399-052-831. E-mail: Fatemeh.zarrabi@monash.edu
}

Received: June 19, 2018 Accepted: August 4, 2018 Online Published: August 6, 2018

doi: 10.5539/elt.v11n9p17 URL: http://doi.org/10.5539/elt.v11n9p17

\begin{abstract}
The present study explores the ways in which English is used in public discourse in Tehran-Iran and the motivations of Iranian - English as a Foreign Language (EFL) learners and teachers towards English language learning. The paper begins with an overview of different places in which English is used in Iran, such as media, public signs, traffic signs, advertisements, products, people's ordinary lives, and education. A cohort of 327 participants, including 168 Iranian EFL learners (male and female) and 159 experienced Iranian EFL teachers (male and female) responded to an English language motivation questionnaire. The results revealed that there is an active presence of English in Iran. In addition, the majority of Iranian EFL learners and teachers involved in the study regard English as an important part of their lives for many and various reasons such as being up-to-date, love, education, learning a new skill, being promoted, having a better and more highly qualified job and increased life chances.
\end{abstract}

Keywords: English language learning, motivation, EFL learners, EFL teachers

\section{Introduction}

First-time visitors to Iran report that Iranian people are kind, hospitable, and eager to communicate in English (Cortazzi et al., 2015). There is a growing interest in English language learning in almost every part of Iran even though English is not spoken as a second language there. There are many reasons why Iranians are interested in learning English (Sadeghi \& Richards, 2015). The purpose of this paper is to explore those reasons with a number of learners and teachers in Iran. In addition, the paper provides a context for this exploration by considering the ways in which English is used in Iran such as in public and private education, academia, media, business, and people's ordinary lives. Thus, we seek to clarify the following research questions:

1) How is English used in Iran?

2) What is the motivation for learning English in Iran?

3) What purposes does English serve for Iranians?

To do this, we have examined the role of English in Tehran, the capital and the largest city of Iran. With a population of around 8.8 million in the city and 15 million in its larger metropolitan area, Tehran is the most populous city in Iran and in Western Asia. Tehran has diversity of people from different cities of Iran, such as Mashhadi, Azeri-Turkish, Kurdish and Gilaki. People from other cities travel to Tehran for better universities and job opportunities. The metropolis of Tehran is divided into 22 municipal districts, each with its own administrative centre. Tehran is located in North West of Iran. The official language of Tehran is Persian but as many people have moved to Tehran from various cities, some might, for example, speak in Turkish, Kurdish, Gilaki or Mashhadi.

The literature has shown that there are many factors affecting English language learning and teaching process (Cheng \& Lee, 2018; Richards \& Sadeghi, 2015; Soureshjani \& Naseri, 2011). Motivation in learning a foreign or second language (FL/L2), among affective factors, plays an important role in education. Dornyei and Ushioda (2011) define motivation as "[w] hat moves a person to make certain choices, to engage in action, to expend effort and persist in action" (p. 3). Motivation has been an area of investigation, particularly in the context of TESOL (Teaching English to Speakers of Other Languages) since it can determine a language learner's success and failure in language learning. Research studies have demonstrated that those students who have higher 
motivation are more successful and efficient in their learning (Ely, 1986; Gardner, 2000). There has been limited research studies in the area of Iranian EFL learners and teachers' motivation for English language learning (ELL) (Richards \& Sadeghi, 2015; Soureshjani \& Naseri, 2011). Therefore, this research study has been conducted to investigate Iranian EFL learners' and teachers' $(n=327)$ motivation for ELL in larger scale as well as showing how the presence of English is in Iran.

\section{Method}

This is a quantitative research study investigating the idea of English in Iran as well as the motivation of EFL learners and teachers for English language learning. The study was conducted in English language institutes in Iran where any Iranian English language learners learn English due to various purposes and motivations.

\subsection{Participants}

In order to explore the motivation of Iranians for learning English, we surveyed two groups of participants: current Iranian English language learners (48.81\% male and 51.19\% female) and Iranian EFL teachers who were themselves previous English language learners ( $45.57 \%$ male and $54.43 \%$ female). It is noteworthy to mention that the participants were chosen through convenient sampling method.

The learners' age ranged from 18 to 63 with the majority being in their twenties and thirties. Several teachers had tertiary qualifications at either undergraduate or post graduate level in English majors such as English language teaching, English translation, or English literature. All the learners and some teachers in this study had majored in other fields than English such as Arts or Engineering. Participants self-assessed as being from all levels of English language proficiency; 10.2 percent of them at Basic level, 5.4 percent Elementary, 15 percent Pre-intermediate level, more than 31 percent at Intermediate level, 19 percent at Upper-intermediate, and 20 percent were Advanced learners. The teachers' age ranged from 22 to 63, with most in their twenties and thirties. The majority of teachers had between 8 to 12 years of English language teaching experience. This shows that we had variety of participants in terms of age, English language learning, and the status of English language learning.

\subsection{Data Collection Procedure}

Questionnaire was chosen to get a general idea on the Iranian EFL learners' and teachers' motivation for English language learning in large scale, however, as motivation is something personal and for each individual might be different, we chose open-ended item questions to give the participants room to talk. Both groups - Iranian EFL teachers and learners - were given a short open-ended survey questionnaire developed after consideration of similar questionnaires (Al-Tamimi \& Shuib, 2009; Kim, 2006; Sadeghi \& Richards, 2015; Tsuda, 2003). The questionnaire included three sections on Background Information, Reasons (Motivation), and Further Information. Before the main administration of the questionnaire, it was piloted on a small group of learners and teachers similar to the target group, and was revised based on pilot findings and expert advice. The Cronbach alpha reliability of the questionnaire was estimated to be 0.71 . The participants had free choice of language for the questionnaire, English or Persian. The questionnaire was administered to EFL teachers and learners in private English language institutes. Half of the questionnaires were filled online via Qualtrics and the rest were administered in person by the researcher. The participants were given as much time as they needed to complete the questionnaires with most learners completing the survey forms in fewer than 20 minutes.

\section{Results and Discussion}

In order to conduct this research study and respond to the above-mentioned research questions, we first looked at the presence of English in different areas of Iran such as in the public domain, the media and education. Then, we explored the motivation of a number of Iranian English language learners and teachers via a short open-ended survey with three hundred and twenty-seven participants.

\subsection{The Status of English in Iran in the Public Domain}

Strong presence of English (along with Persian) is clearly obvious in public life as is reflected in street names, traffic signals, and public signs and messages (Figure 1). Iranian English newspapers such as the Tehran Times and Iran Daily, monthly English periodicals (e.g. VIVA magazine), as well as channel 4 which broadcasts English news programs and documentaries (on wildlife, lives of famous people, landmarks, etc.) are also available in Iran (Figure 2). The audience and readers would typically be foreigners living in Iran and students who enjoy learning English or who are majoring in English and want to boost up their English knowledge or develop their English language skills. 

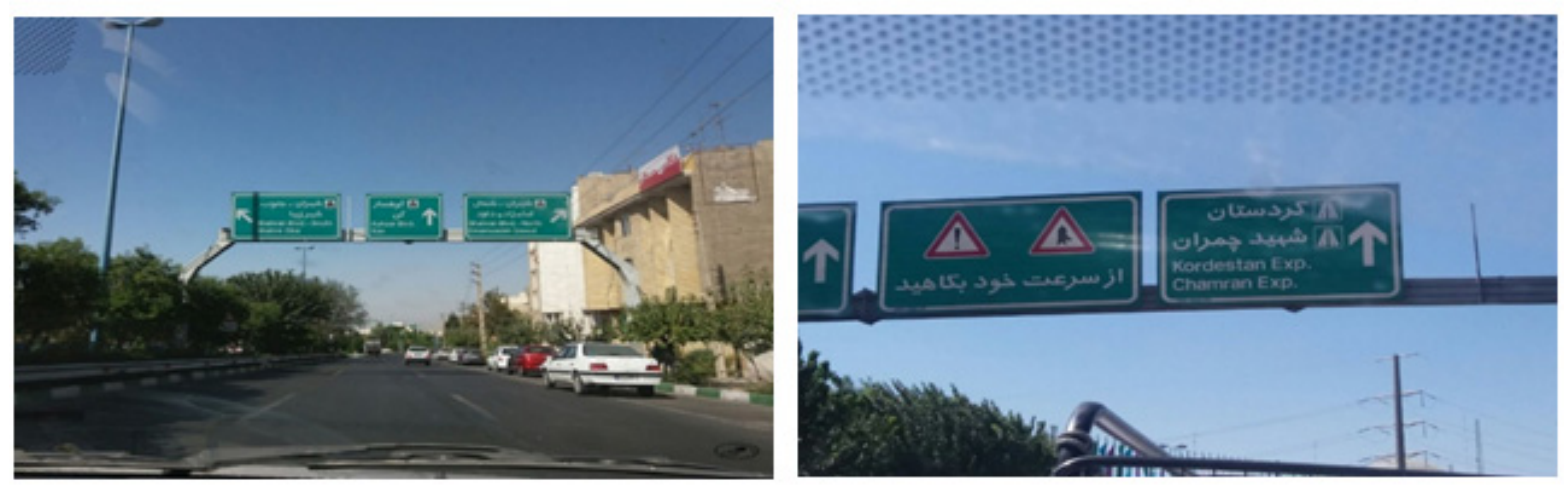

Figure 1. Traffic signals and highways, Tehran, Iran

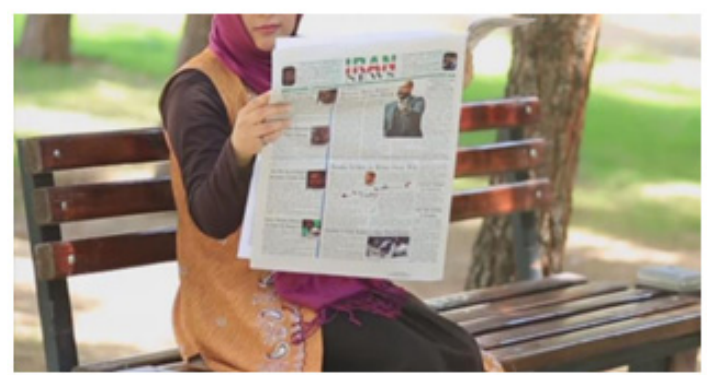

Figure 2. Iran News, an English language newspaper

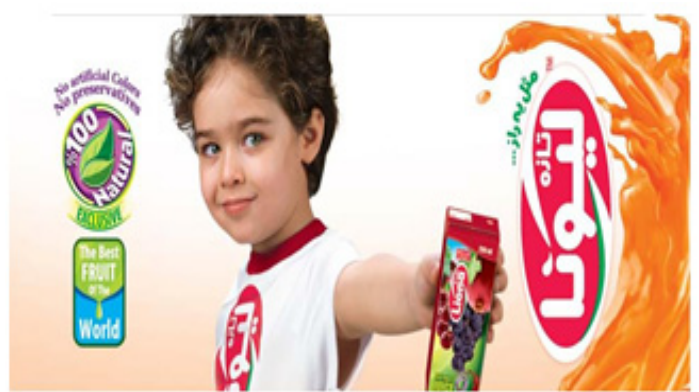

Figure 3. Fruit juice advertisement on TV in Iran

English is not a second language in Iran and is not used as a means of communication - orally or written - in many Iranian organizations. However, English language knowledge together with computer literacy, is considered as an advantage over other employees in almost all private and public workplaces in Iran. Thus, English is seen as a worthwhile asset, one that enables people to interact with a wider world, to be educated abroad, to experience living abroad, to earn credits and prestige, to be up-to-date through use techno-gadgets, and to advance themselves in their jobs (Sadeghi \& Richards, 2015).

English is viewed as a necessary tool for communication with the world beyond Iran's borders and as a means of providing access to information required for Academic technical and scientific texts in this globalized digital era (Dao \& McDonough, 2018; Kiany et al., 2011; Zarrabi, 2017). Furthermore, English is viewed as cool and modern (prestigious) in Iran as well as a means of providing information for tourists and visitors who do not understand Persian (Sadeghi \& Richards, 2015). This perspective is reflected in advertisements (Figure 3), trading billboards, clothing items, domestic products (e.g. chocolates, snacks and dairy products, Figure 4), hotels (Figure 5), shops (Figure 6), and restaurants (Figure 7) through the use of English words/phrases or the use of letters from the English alphabet to express Persian words (Figure 4). This use of English can result in funny mistakes which appear in social media as jokes. Some English words have become an integrated part of Persian language such as bank (Figure 8), park, hotel (Figure 5), sandwich, jean[s], as well as some techno-words such as laptop, mobile, telephone, tablet and so on. In addition, many in the younger generation use English 'orthography' for their Persian text message communications and emails (Figure 9). English graffiti, especially romantic messages, are also found on many walls in Iran. 


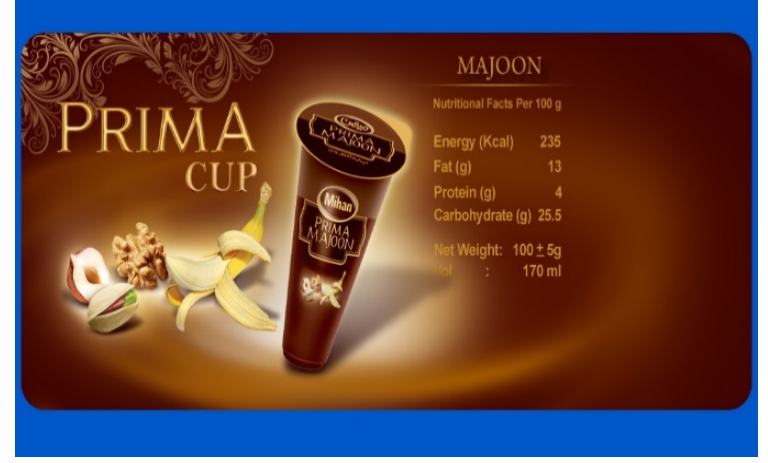

Figure 4. Majoon Ice cream, Iran Figure

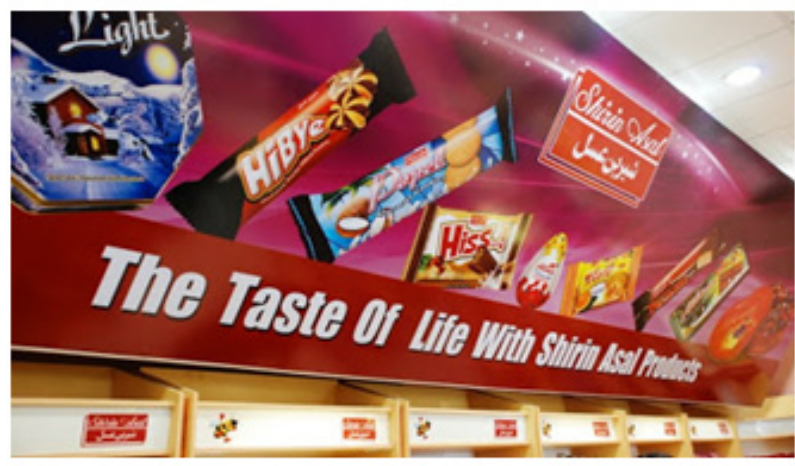

Figure 6. Shirin Asal shop in Tehran, Iran

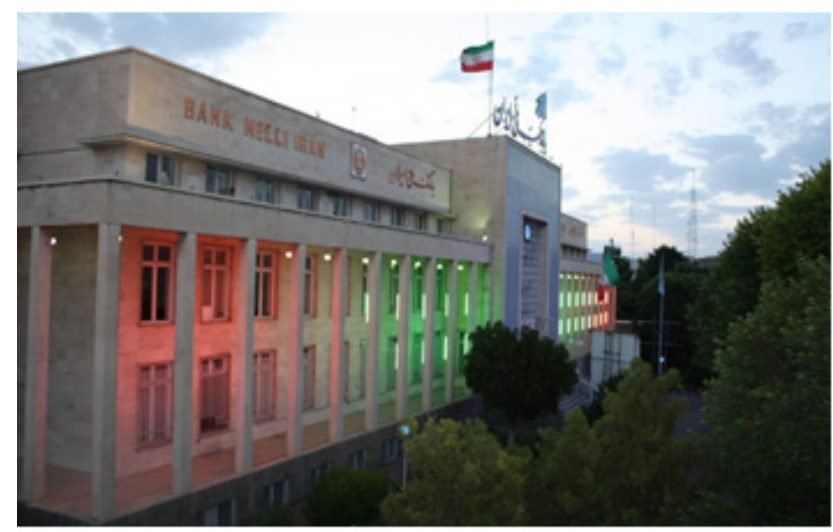

Figure 8. Melli bank in Tehran, Iran

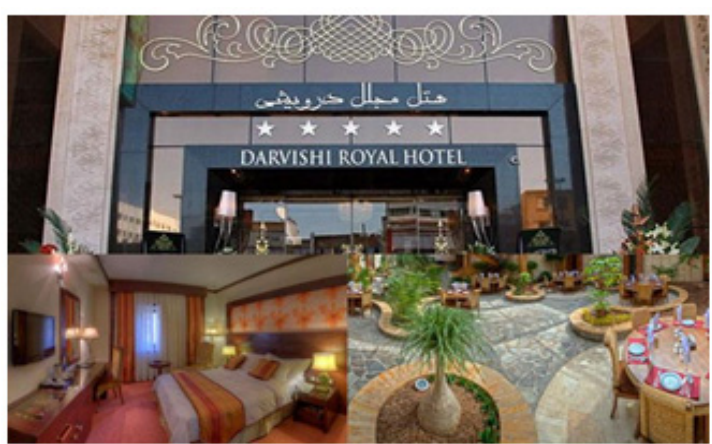

Figure 5. Darvishi Royal Hotel in Mashhad, Iran

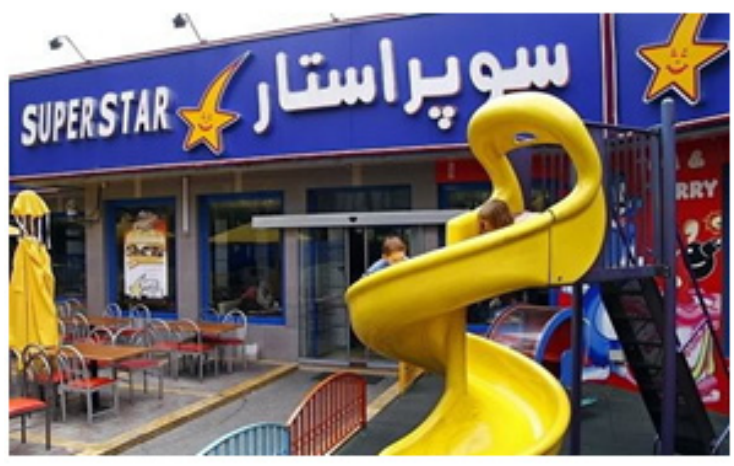

Figure 7. Super Star restaurant in Tehran, Iran

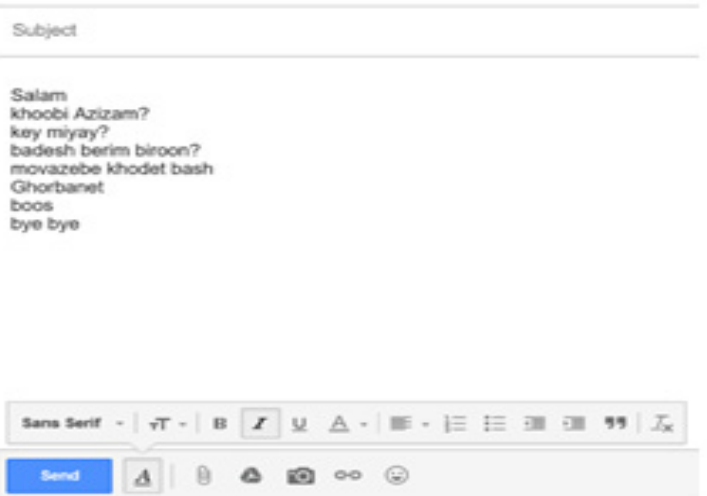

Figure 9. Farsi text message or email in English letters

Doctors' prescriptions are all in English. So those who do not know English cannot understand what the doctor has prescribed for them. From the examples mentioned earlier, it is obvious how widely English is used in Iran although it is not as a second language. What follows is a clear explanation of English in Educational system of Iran, both in schools and higher education.

\subsection{English in the Educational System of Iran}

In the official curriculum of public education, English is a compulsory course for junior high and high school students (based on the official website of Organization for Curriculum Development (TALIF), www.talif.sch.ir, 18/04/2018). The starting age of formal literacy education for Iranian children is seven (Palls, 2010) and starting age for learning English is twelve - Grade 6 - and is continued at tertiary level in either General English or English for specific/academic purposes [ESP/EAP] courses.

Unlike English in school education, there is no specific course book material and syllabus for teaching English at university. The lecturers can develop their own syllabus and select the most relevant teaching material. Some 
university lecturers choose the SAMT (the organization in charge of producing educational materials for universities in Iran) publication for English at tertiary level while others choose books published outside Iran (Hosseini et al., 2009). Typically, English courses at universities in Iran focus mainly on reading comprehension and emphasize learning grammar and vocabulary with virtually no attention paid to speaking skills and communicative competence. Most classes are conducted in Persian (except those for TESOL, TEFL, and English literature majors) and take up between twenty to thirty hours, and might not be taught by staff from an English department (Eslami et al., 2007; Mazdayasna \& Tahririan, 2008). Majors like TESOL/TEFL, English literature, and Translation exist in many universities in Iran and are taught by academics who are specialized in these areas.

English has been viewed from three different perspectives in the educational system of Iran: pre-revolution (before 1978), during the revolution (1979-1981), and post-revolution (1982 to present). In the first period, the view towards English language learning was positive with the focus on vocabulary learning; in the second period, which goes back to the Islamic Revolution in 1978, English was described as a "foreign" or "alien" language (Borjian, 2013; Davari \& Aghagolzadeh, 2015); in the last period, in contrast to the previous view, English is regarded as an essential tool for progress and communication (Riazi, 2005; Sadeghi \& Richards, 2015). This shift in perspective was caused, at least in part, by a famous sermon by Iran's late leader (Imam Khomeini, PBUH). He believed that foreign languages, especially English which is the universal language and the language of world media, should be included in the Iranian school syllabi (information based on the official website of Organization for Curriculum Development, TALIF; www.talif.sch.ir, 18/04/2018). School English course books have been changed four times in response to the changed attitudes towards English, two modifications in the pre-revolution series and two in the post-revolution series (www.talif.sch.ir, 18/04/2018). Despite these changes, all textbooks are based on a single approach to English language teaching, the Grammar-Translation Method (GTM, Figure 10). One of the disadvantages of the approach to teaching English in schools in Iran is the use of purely GTM as it only teaches students grammar without context, translation, and lists of vocabulary (Dahmardah, 2009). Another problematic feature of school English classrooms in Iran is the seating arrangements which are in orderly rows (Figure 11) with the teacher always at the front. More effective seating arrangements for English classes are a horseshoe, circle and separate tables (Figure 12) which increase the ease of communication between students. Poorly prepared school English teachers, physical limitations of the classes such as seating arrangements and lack of audio system in each class, as well as inappropriate school textbooks and teaching methodologies are all pivotal factors which result in the poor English language proficiency of Iranian students (Borijan, 2013). Therefore, the students learn merely translation, grammar, and vocabulary. In fact, all four skills, reading, writing, speaking, and listening, are weak after graduation unless students go to private English language institutes.

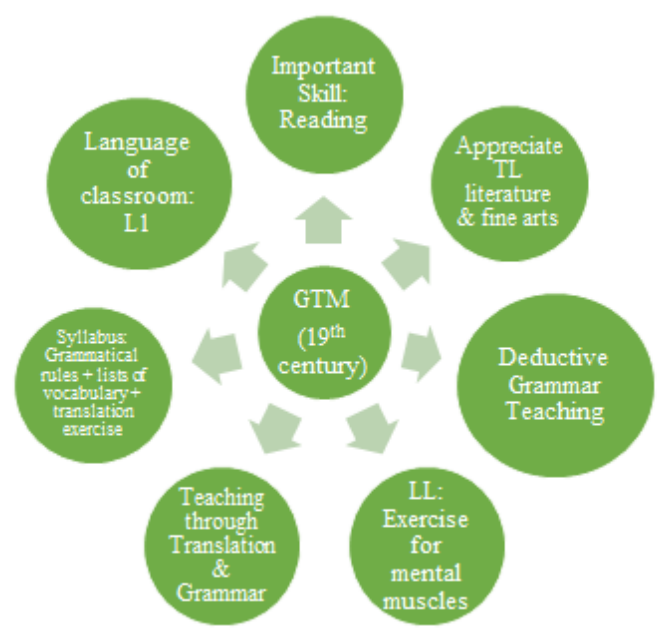

Figure 10. GTM adapted from Richards \& Rodgers, 2001, LL = Language Learning, L1 = Mother tongue, $\mathrm{TL}=$ Target Language

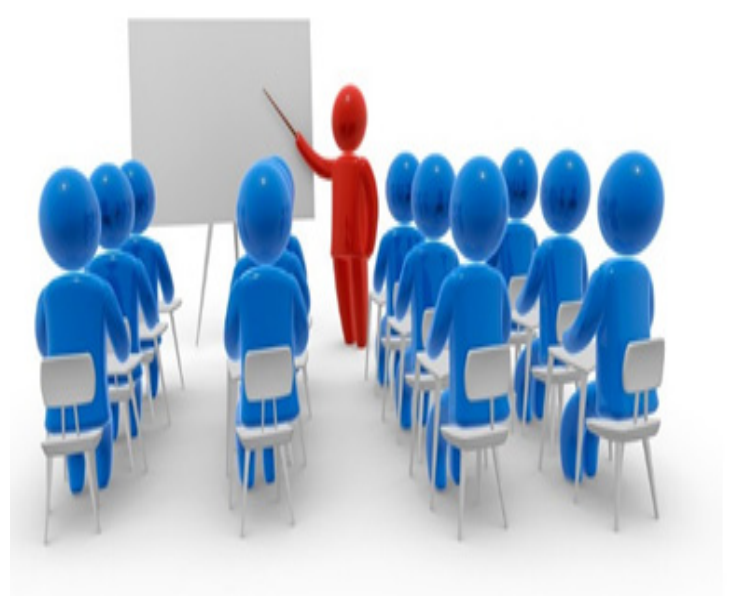

Figure 11. Iran seating configuration of the classes at schools 


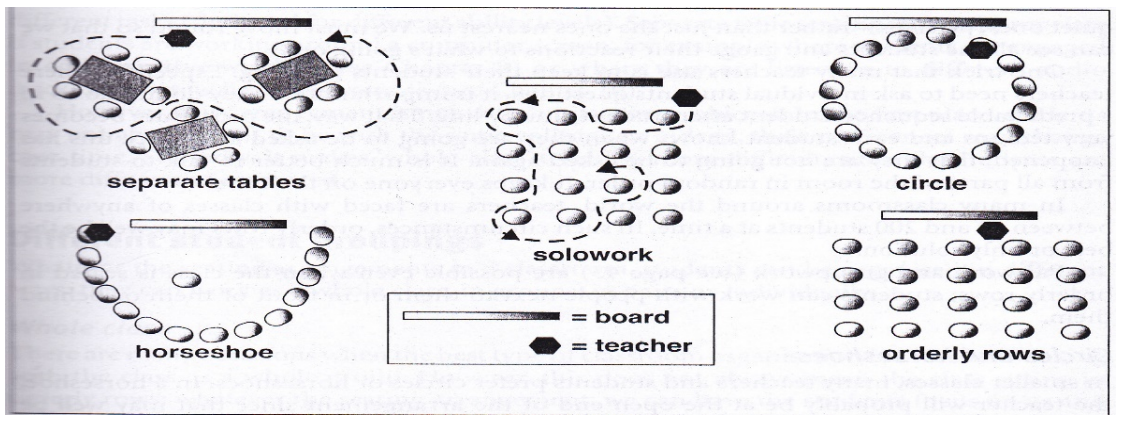

Figure 12. English classroom seating arrangements, Harmer (2007)

Iranian EFL students have revealed that they consider English language learning as either "important" or "somewhat important" to their lives (Meshkat \& Saeb, 2013; Ardavani \& Durrant, 2015). Given this, combined with the lack of communicative competence among many language learners as a result of the dominant pedagogy, there is a high demand for private English institutions in Iran (Sadeghi \& Richards, 2015). Although English is considered as a foreign language in Iran, countless numbers of people want to learn it. There are more than seven thousand and eight hundred registered English language institutes in Iran (including 4350 for females and 3450 for males) in addition to numerous unregistered ones where the Iranians learn English - either ESP or General English - in order to be able to communicate in English, to pursue education abroad, to live abroad, to travel to foreign countries, and to take international examinations such as IELTS/TOEFL/GRE (Iran Ministry of Education, personal communication, 18/04/2018). The number of students in various institutes differs in size, ranging from those with 50 students to those with more than 2000 students. Registrations usually double during the summer period which is school holiday. In addition to studying at English language institutes, some parents employ private tutors to teach their children at home (based on the author's personal experience). All English classes at private institutes are conducted in English. The teachers in English institutes - either majors in English or not - are fluent speakers of English and teach popular textbooks such as Interchange, True to Life, Headway, and English Result. These books are accompanied by teachers' guide, workbook, and audio-visual aids, as well as other pedagogical tools which are provided by the institutions. In the more famous institutes, teachers participate in career development workshops and apply the newest ELT methodologies in their classrooms.

Following a comprehensive research on the status of using English in both public domain and educational system of Iran, investigating the motivation of English language learners in Iran, was set as the agenda for the current research.

\subsection{Motivation for English Language Learning}

In the 'general information' section, we asked about "Where they have learned English?" to get a general idea of what is a common way for the Iranians to learn English. The results (Figure 13 \& Figure 14) show that the majority of both groups (EFL learners $67 \%$ and EFL teachers $44 \%$ ) identify private language institutes as the main context for their language learning.

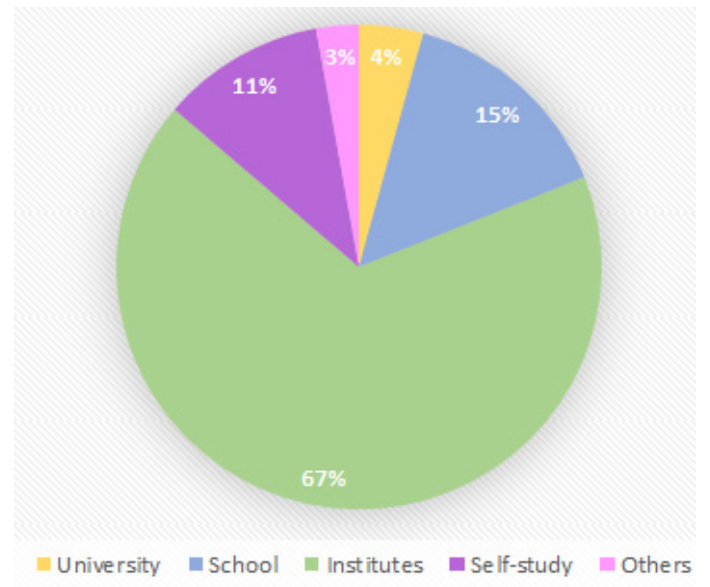

Figure 13. Where student participants learn English

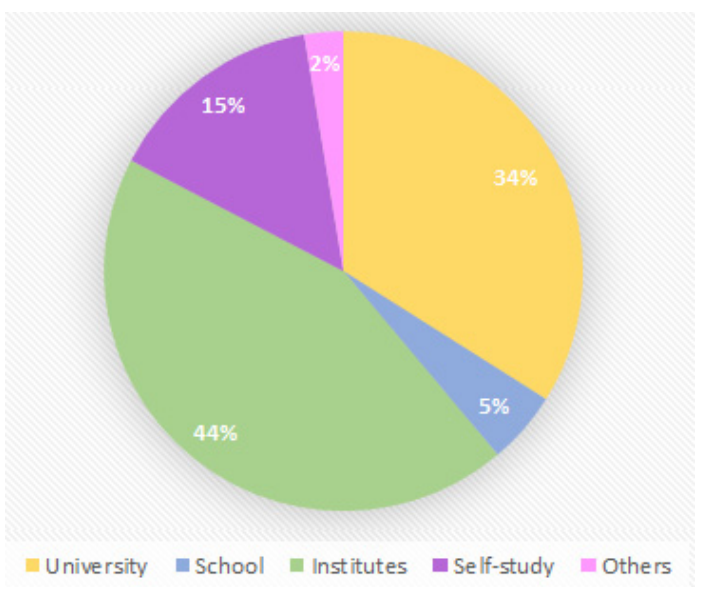

Figure 14. Where teacher participants learnt English 


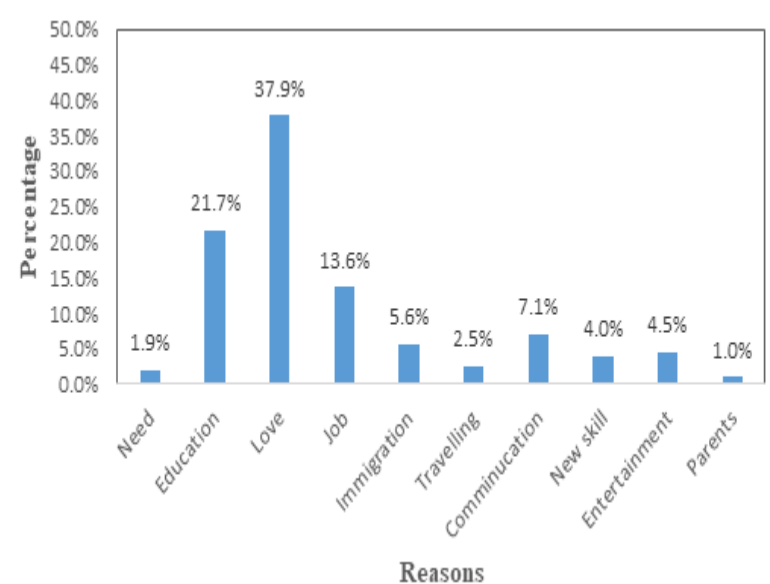

Figure 15. Why student participants learn English

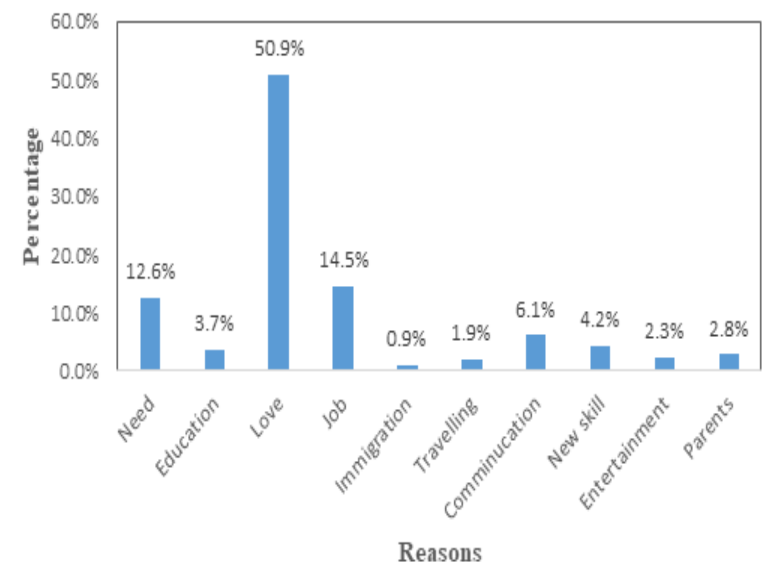

Figure 16. Why teacher participants learnt English

As demonstrated in Figure 15 and 16, more than 37\% of EFL learners and approximately 51\% of EFL teachers said they learn English due to their "love" of the English language. When they were further asked what they mean by "love", they said that they love English because it sounds beautiful to them, that knowing a language which others in the community might not know or understand is nice, knowledge of English is a luxury, or simply because they love their English teacher. Some also said "I don't know but I love it". This result corresponds with the research findings of Sadeghi and Richards (2015). After "love", "education" received the greatest percentage for EFL learners with $21.7 \%$, while it is $3.7 \%$ for EFL teachers. By educational purposes, they meant different aspects of education, such as their major at university (TESOL/translation/ English literature), compulsory academic English for non-English majors (e.g. engineering), continuing their education abroad, taking IELTS/TOEFL/GRE exams, passing the university entrance exam, pursuing higher education such as a doctorate because, even though the final thesis may be submitted in Persian, English is a requirement for entry to doctoral studies, or accessing more international resources or journal papers required for their university study. The third place goes to "job" for EFL learners with 13.6\%, while it is the second highest reason for EFL teachers with $14.5 \%$. Participants said that higher and better-qualified jobs in Iran are connected with knowledge of English. Some learner participants wanted to be English language teachers while others had to communicate with foreign experts due to their jobs. Then "communication" comes to the fourth place with $7.1 \%$ for EFL learners and $6.1 \%$ for EFL teachers. Those who mentioned they learn English to communicate with native speakers said they are interested in communicating with a wider range of people from other nationalities. Some wanted to communicate while they are traveling; others believed that human beings are alive due to relationships and communication so it is good to learn English which enables them to communicate with people from other countries. A few wanted to communicate with relatives living abroad who are more fluent in English than Persian. After that, "immigration" got the fifth place for EFL learners with $5.6 \%$; this is the least important reason for EFL teachers with only $0.9 \%$. Some of the participants planned to immigrate so that is why they learn English. "Entertainment" is in the sixth place with $4.5 \%$ for EFL learners, while it is in 8 th place for EFL teachers with $2.3 \%$. Some said they want to learn English because they want to read English books for pleasure, watch English movies, listen to English songs, read English magazines, and surf the net in English and be up-to-date in their knowledge of the world outside Iran. Learners and teachers equally indicated that they learn/learnt English because it is a "new skill". Some believed that being fluent in English is a new skill which leads to a new world and new experiences which will improve and progress the learners. Then "travelling" is in $8^{\text {th }}$ place with $2.5 \%$ for the EFL learners and $9^{\text {th }}$ place for the EFL teachers with $1.9 \%$. They all mentioned their love of traveling abroad and the desire to communicate with foreigners easily. They also believed that a person can only have complete information about the place and culture she/he is visiting through knowing English, the international language. After that, "need" is in $9^{\text {th }}$ place with $1.9 \%$ for the learners but in third place for EFL teachers with 12.6\%. By using the word "need", they meant English is the international language and everyone needs it in this new era. They believed that in this century, a person without the knowledge of computers and of English is functionally illiterate. In addition, they mentioned it is impossible to live effectively without knowing English. Finally, the influence of "parents" is $1.0 \%$ for learners, and in the seventh place for teachers with $2.8 \%$. These outcomes suggest that, at least in this participant group, learners, either current or previous, learn English language voluntarily. Although some mentioned that initially their parents had forced them to learn English, 
however this had a positive effect as they fell in love with English as a result. Given that participants were either current or present students at a private language institute or working as English language teachers, this result is to be expected. Results for a group less intimately connected with the language may well be very different.

In general, findings are in-line with the research results of other scholars such as Ardavani and Durrant (2015) and Meshkat and Saeb (2013). They all demonstrate that many Iranians are highly motivated to learn English, which means that they regarded learning English as 'important' skill in their lives and the least Iranians learn English by force of parents or others. Despite a slight difference in the percentage of each motivation type, our observations lend support to Sadeghi and Richard's (2015) claim that the majority of Iranians learn English because they love it.

\section{Conclusion}

This paper aimed to explore the status and idea of English in Iran as well as the motivations for learning English. We first examined the functions English serves in Iran to provide a context for the next stage of the study and then conducted 327 survey questionnaires in different English language institutes among both learners and teachers in various areas of Tehran. The study provides a window of understanding of the different purposes for which people use and learn English as well as of its presence in the public domain, education, and the media.

Some of the most common reasons for participants to learn English are love of the language, intending to continue their education abroad, to travel, to communicate with native speakers, to watch English movies, to live abroad, to find a good job, and to earn credit (since English is regarded as prestigious by many Iranians). Others love to learn English because they enjoy listening to English songs, reading English books, or simply because they love their English teacher.

Although the limitations of the study are acknowledged in that participants were actively involved as either learners or teachers of English, the results clearly indicate that English language and English language learning is regarded as a worthwhile asset. While further research is called for to investigate the degree of success in English language learning, the findings may serve as a useful resource in planning for English language teaching in Iran and English course-book material development that responds to the motivations for English language learning. In addition, further research could be conducted on investigating the EFL learners' motivation for English language learning considering extrinsic, intrinsic, and integrative scales.

\section{Acknowledgments}

I would like to thank Mrs. Mahnaz Ghavifekr, the manager of Zohreh Novin English language Institute, Mr. Arash Shekarian from Chista Language Institute for their help and support during the data collection. I also appreciate the participation of all the English learners and teachers from different Iranian English language institutes.

\section{References}

Ardavani, S., \& Durrant, P. (2015). "How Have Political and Socio-Economic Issues Impacted on the Motivation of Iranian Students to Learn English?" In English Language Teaching in the Islamic Republic of Iran: Innovations, Trends and Challenges, edited by Chris Kennedy, (pp. 35-48). London: British Council.

Borjian, M. (2013). English in Post-revolutionary Iran: From Indigenization to Internationalization, 29. Clevedon: Multilingual Matters. https://doi.org/10.2307/j.ctt21kk1tj.10

Cheng, A., \& Lee, C. (2018). Factors affecting tertiary English learners' persistence in the self-directed language learning journey. System, 76, 170-182. https://doi.org/10.1016/j.system.2018.06.001

Cortazzi, M., Lixian, L., Shiva, K., \& Majid, N. (2015). Candles Lighting up the Journey of Learning: Teachers of English in Iran. In C. Kennedy (Ed.), English Language Teaching in the Islamic Republic of Iran: Innovations, Trends and Challenges (pp. 123-138). London: British Council.

Dao, P., \& McDonough, K. (2018). Effect of proficiency on Vietnamese EFL learners' engagement in peer $\begin{array}{llll}\text { interaction. International Journal of Educational Research, 88, 60-72. } & \text {. }\end{array}$ https://doi.org/10.1016/j.ijer.2018.01.008

Dihmardah, M. (2009). English Language Teaching in Iran: English Language Teaching in Iran and Communicative Pedagogy. Saarbrucken, Germany: VDM Verlag Dr. Muller.

Dornyei, Z., \& Ushioda, E. (2011). Teaching and researching motivation (2nd ed.). Harlow: Longman.

Ely, C. (1986). Language learning motivation: A descriptive and causal analysis. Modern Language Journal, 70, 28-35. https://doi.org/10.1111/j.1540-4781.1986.tb05240.x 
Eslami, Z. R., Eslami-Rasekh, A., \& Quiroz, B. (2007). Needs analysis of Iranian EAP students. ESP across Cultures, 4, 21-37.

Gardner, R. C. (2000). Correlation, causation, motivation, and second language acquisition. Canadian Psychology, 41, 1-24. https://doi.org/10.1037/h0086854

Hosseini, F. A., Khajavy, G. H., \& Choi, C. W. (2016). Testing a model of intercultural willingness to communicate based on ethnocentrism, ambiguity tolerance, and sensation seeking: The role of learning English in Iran. Journal of Intercultural Communication Research, 45(4), 304-318. https://doi.org/10.1080/17475759.2016.1190776

Kiany, G. R., Mahdavy, B., \& Ghafar, S. R. (2011). Towards a Harmonized Foreign Language Education in Iran: National Policies and English Achievement. Literacy Information and Computer Education Journal, 2, 462-469. https://doi.org/10.20533/licej.2040.2589.2011.0064

Mazdayasna, G., \& Tahririan, M. H. (2008). Developing a profile of the ESP needs of Iranian Students: The case of students of nursing and midwifery. Journal of English for Academic Purposes, 7, 277-289. https://doi.org/10.1016/j.jeap.2008.10.008

Meshkat, M., \& Saeb, F. (2013). High School Students' Beliefs about Language Learning. ROSHD ELT, 28 , 50-55.

Palls, B. (2010). Cultural portraits: A synoptic guide (2nd ed.) Clearwater Beach, FL: B\&B Educational Consultants.

Riazi, A. (2005). The four language stages in the history of Iran. In A. M. Y. Lin, \& P. W. Martin (Eds.), Decolonization, globalization: Language-in-education policy and practice (pp. 98-114). Clevedon, UK: Multilingual Matters.

Richards, J. C., \& Rodgers, T. S. (2001). Approaches and Methods in Language Teaching. Cambridge: Cambridge University Press. https://doi.org/10.1017/CBO9780511667305

Sadeghi, K., \& Richards, J. C. (2015). The idea of English in Iran: an example from Urmia. Journal of Multilingual and Multicultural Development.

Soureshjani, K. H., \& Naseri, N. (2011). The Interrelationship of Instrumental, Integrative, Intrinsic, and Extrinsic Motivations and the Lexical-oriented Knowledge among Persian EFL Language Learners. Theory and Practice in Language Studies, 1(6), 662-670. https://doi.org/10.4304/tpls.1.6.662-670

Zarrabi, F., (2017). Investigating the Relationship between Learning Style and Metacognitive Listening Awareness. International Journal of Listening, 1-13. https://doi.org/10.1080/10904018.2016.1276458

\section{Internet Sources}

www.amar.org.ir, Iran's National Centre for Statistics.

www.talif.sch.ir, TALIF (Organization for Curriculum Development).

www.trading economics.com, Trading Economics.

\section{Copyrights}

Copyright for this article is retained by the author(s), with first publication rights granted to the journal.

This is an open-access article distributed under the terms and conditions of the Creative Commons Attribution license (http://creativecommons.org/licenses/by/4.0/). 